\title{
Recurrent Childhood Giant Cell Glioblastoma
}

National Cancer Institute

\section{Source}

National Cancer Institute. Recurrent Childhood Giant Cell Glioblastoma. NCI Thesaurus.

Code C115363.

The reemergence of giant cell glioblastoma in childhood after a period of remission. 